\title{
The Financing Behaviour of the CEE Firms under the Impact of Financial Crisis: A Panel Regression Approach
}

\author{
Valentina Diana RUSU ${ }^{1}$, Angela ROMAN ${ }^{2}$
}

\begin{abstract}
This paper studies empirical association between global financial shocks and firm behaviour towards liquidity needs across emerging countries from Central and Eastern Europe. Through this paper we aimed to identify the impact of the recent financial crisis on the financing decisions of the firms in seven Central and Eastern European countries (namely Bulgaria, Estonia, Latvia, Lithuania, Poland, Romania and Hungary). Using three multiple linear regression models, we wanted to observe the changes that appear in the use of various sources of financing as a result of the modification of five macroeconomic factors. The results obtained from the three multiple linear regression models show that in the context of the recent financial crisis, the financing decision of firms in the seven countries considered in the analysis was significantly influenced by the changes registered by four macroeconomic factors, respectively the interest rate on loans, the domestic credit granted to private sector, the inflation rate and the real GDP growth rate. Overall, our study highlights that the macroeconomic environment has a major impact on the financing behaviour of the firms.
\end{abstract}

Keywords: capital structure, financing behaviour, macroeconomic factors, financial crisis, panel data

\section{Introduction}

The financing decision concerns determining the most efficient financing sources for an enterprise, for example that sources that implies the lowest costs. Also, this decision wants to determine the best mix of financing sources, settling the proportions of equity and borrowed capital. Either way, this decision is specific to each company and to each project. Choosing the ways of financing is a fundamental decision of the firm's financial policy. This decision regards, on the one hand, determining the volume of external financing and internal financing that will be used for financing the activities and, on the other hand, the choice of composition of external financing: equity or debt.

The problems of financing are vital for the firm because their settlement conditions its survival, the prospects for its development, its present and future performance, the autonomy of its owners and managers.

The financing decision at microeconomic level is significantly influenced by how the economic mechanisms at regional, national and even global level work. Thus, companies are currently operating in a complex environment, characterized by instability. 
In this complex environment the financial crises are becoming more frequent, being a recent topic in the modern economy. Financial crisis are recurrent events with varying degrees of severity. However, we can talk about the crisis in different contexts and at different temporal and historical moments. The crisis that outburst in 2007 is the worst financial crisis since the 1930s. In some respects it resembles with other crises emerged in the last twenty-five years, but it is also net different because the recent crisis marks the end of an era of credit expansion.

The recent global financial crisis corresponds too many other patterns of previous financial crises widespread in developed countries and in developing ones. Although there is a rich historical literature dealing with the economic cyclicity, alternating periods of economic boom with the crisis and recession, the most important models barely beginning to be identified and analyzed.

Recurring financial crises have brought questions about the rationality of markets but also questions about how rational actors end up being caught several times in the investment boom's anger which eventually result in panic and financial crisis. As Kindleberger and Aliber [25] said, the world economy in recent centuries has been the subject of a series of financial "manias, panics and crashes" that have shattered the international financial capitalism.

The recent financial crisis provides an opportunity to investigate the effect of a financial shock on capital structure of the firms. Bhamra et al. [7] find that firms are more conservative in their financial policy knowing that there is a possibility of rare economic crises. In this context, we propose to identify the changes that occurred in the financing decision of the enterprises in crisis conditions, by analyzing a couple of econometric models. The purpose of this paper is to empirically investigate whether the recent financial crisis has had a significant impact on the financial structure of the firms which operate in seven countries from Central and Eastern Europe (namely Bulgaria, Estonia, Latvia, Lithuania, Poland, Romania and Hungary).

In order to achieve the research objective we have structured our paper as follows: section 2 presents a brief review of the empirical literature regarding the determinants of the financial structure of the firms; section 3 describes the data, the selected variables and the methodology of research, section 4 presents the main results of our empirical analysis and the final section concludes.

\section{Theory and hypothesis}

In this paper we provide an analysis on the impact of the crisis on the financing decisions made by the corporations from the seven CEE countries.

The development or inhibition of firms' activity may be due to internal factors and objective macroeconomic factors, on which entrepreneurs cannot act. In the last decades increasingly more studies [31], [16], [20] have examined the financial structure of firms and its determinants. Most of these studies show that the dominant source of corporate financing is represented by internal financing, for example the reinvested profit. Regarding other sources of financing (e.g., issuance of shares, bank loans and other type of debt), there are important differences between countries according to their economic and financial characteristics. Regarding the macroeconomic factors that determine the 
differences between countries on the financing of the firms the studies conducted until now have not a unitary approach.

The study realized by Beck et al. [5] reflects, based on a survey that has included 10.000 firms from 80 countries, the fundamental factors to which depends the firms' access to finance. Thus, the study highlights the relationship between the access to finance for enterprises and their characteristics, such as age, size and ownership structure. From this perspective, the authors find that young firms of small size as well as national ones face greater obstacles when they seek to obtain financial resources. The study also highlights the relationship between the degree of economic and financial development of a country and the access to finance for firms.

Ardic et al. [2] analyze, using statistical data, the macroeconomic and institutional factors that are influencing the firms financing through loans. The authors have found a positive correlation between the degree of economic and financial development of a country and the firm's financing level.

Talking about the impact of macroeconomic instability on firms the internationally studies realized by the World Bank [11], [12], [13] showed that the enterprises in Central and Eastern European countries were significantly affected by the recent financial crisis, registering reductions in net revenue from the activity.

A survey realized on the real effects of financial constraints during financial crises reveals that constrained firms, in these conditions, use internal funding and put more effort in obtaining credit from the banks anticipating restricted access to credit in the future [9].

Firms in emerging markets are more vulnerable to credit-market shocks than are firms in developed countries [24].

Besides the internal conditions of the firm, the second type of factors that influence the choice of capital structure of firms is represented by the macroeconomic conditions. Antoniou et al. [1] find similarities regarding the determinants of capital structure among the countries they have investigated, but the importance of these factors varies between the countries. The authors highlight that firm specific factors cannot altogether explain capital structure so it is also of interest the examination of country specific factors. They also find evidence that the macroeconomic environment is important in explaining capital structure choice, but again the importance of this varies between the countries investigated. De Jong et al. [15] also show that, besides firm specific factors, country specific factors matter in capital structure decisions.

Starting from these assessments, in our analysis, we have chosen seven countries from Central and Eastern Europe in order to see if the effect of the changes in macroeconomic conditions has affected differently the financing decisions of firm from different countries.

\section{Method}

\subsection{Sample and data}

This paper explores macroeconomic determinants of capital structure of firms and examines the impact of the 2007-2008 financial crisis on the determinants of capital structure of 245 corporations from seven emerging countries from Central and Eastern Europe (namely Bulgaria, Estonia, Latvia, Lithuania, Poland, Romania and Hungary). 
The annual financial data for the firms in the analyzed countries were obtained from the AMADEUS database managed by the Bureau van Dijk [8], which provides comparable financial information for approximately 14 million of public and private companies across Europe, for the period 2004-2009. The selection of the firms was guided by the availability of data. Further, the firms in the financial sector (such as banks, insurance and investment companies) were not considered due to the fact that they tend to have a distinct capital structure towards industrial firms [35].

The main problem we faced when we decided to perform an econometric analysis of the changes that appeared in the financing decision of the firms under the impact of the recent financial crisis has been linked, first, with the fact that the determinants of the financing decision of firms can be measured by more variables and there exist the risk of being chosen that variables that are not the best for the purpose of this research. Secondly, it is extremely difficult to identify those variables that measure the determinants of the financing decision and that do not depend on other factors. More specifically, a variable contained in a given econometric model may actually represent several factors influence on the financing decision.

However, the interest in validation of an econometric model of the recent financial crisis impact on the financing decision of the firms in emerging countries of Central and Eastern Europe was actually the start point of the research conducted in this paper.

In the econometric analysis, we did not include the microeconomic factors exercising influence on the financing decision of firms, because we were interested in particular in the impact of the shocks and changes in the external environment, arising from the manifestation of the recent financial crisis, on the financing decision of the companies. Regarding the influence of the microeconomic factors on the financing decision of enterprises in developing countries, there have been carried out many studies, like: [26], [30], [28], [19], [14], [27], [32]. The mentioned studies indicate that the financing structure of the firms from the considered countries is significantly influenced by the profitability, tangibility, company size, growth opportunities, firm age and income variability. Thus, we consider that is required a recent study, to analyze the influence of macroeconomic factors and especially the impact of the recent financial crisis.

Table 1. Explanatory variables and their expected relation with dependent variable

\begin{tabular}{|l|l|l|l|}
\hline $\begin{array}{l}\text { Variable } \\
\text { (Abbreviation) }\end{array}$ & Measurement & $\begin{array}{l}\text { Expected } \\
\text { sign* }\end{array}$ & Rationale \\
\hline $\begin{array}{l}\text { Interest rate } \\
\text { (IRL) }\end{array}$ & $\begin{array}{l}\text { The interest rate on loans } \\
\text { of commercial banks used } \\
\text { as the proxy for interest } \\
\text { rates (annual \%) }\end{array}$ & $\begin{array}{l}\text { The interest rate on loans of commercial } \\
\text { banks is chosen because in the CEE } \\
\text { countries the corporate sector loans are } \\
\text { obtained from commercial banks }\end{array}$ \\
\hline $\begin{array}{l}\text { The foreign } \\
\text { investments } \\
\text { (FDI) }\end{array}$ & $\begin{array}{l}\text { The value of foreign direct } \\
\text { investment as a \% of } \\
\text { GDP }\end{array}$ & + & $\begin{array}{l}\text { Firms in developing countries call credit } \\
\text { constraints as one of the main obstacles } \\
\text { to investment, thus, foreign investments } \\
\text { eases credit constraints felt by enterprises, } \\
\text { by introducing capital, supplementing the } \\
\text { limited resources }\end{array}$ \\
\hline $\begin{array}{l}\text { Gross domestic } \\
\text { product (GDP) }\end{array}$ & $\begin{array}{l}\text { Real GDP as proxy for } \\
\text { economic growth (annual } \\
\%)\end{array}$ & $+\begin{array}{l}\text { During the good time, the firm resort to } \\
\text { debt financing to finance their expansion } \\
\text { programs } \\
\text { If the financial resources provided to }\end{array}$ \\
\hline Domestic credit & Financial resources & + & \multicolumn{2}{|c|}{} \\
\hline
\end{tabular}




\begin{tabular}{|l|l|l|l|}
\hline $\begin{array}{l}\text { to private sector } \\
\text { (DCPV) }\end{array}$ & $\begin{array}{l}\text { provided to private sector } \\
\text { through loans (as \% of } \\
\text { GDP) }\end{array}$ & $\begin{array}{l}\text { private sector through loans are } \\
\text { increasing then the firms will benefit } \\
\text { from them increasing the share of loans } \\
\text { in their capital structure }\end{array}$ \\
\hline $\begin{array}{l}\text { Inflation rate } \\
(\mathrm{CPI})\end{array}$ & $\begin{array}{l}\mathrm{CPI} \text { is measured as a } \\
\text { proxy for Inflation (annual } \\
\%)\end{array}$ & $\begin{array}{l}\text { During an inflationary period, firm } \\
\text { employs more debt in their capital } \\
\text { structure as the real cost of debt falls }\end{array}$ \\
\hline
\end{tabular}

* according to the results of previous empirical studies.

Source: the authors

The development or the inhibition of the business activity may be due (in addition to internal factors) to some objective macroeconomic factors on which entrepreneurs cannot operate. Thus, when choosing the explanatory variables used in the econometric analysis, we have considered five macroeconomic indicators whose evolution determines, to a certain extent, the financing decision of firms, namely: the interest rate (IRL), the foreign investments (FDI), the gross domestic product (GDP), the domestic credit to private sector (DCPV) and the inflation rate (CPI). The values for these variables have been reviewed for each of the seven countries in part (Bulgaria, Estonia, Latvia, Lithuania, Poland, Romania and Hungary) and, we have analyzed the trends of this indicators for a time span of six years (2004-2009), and also the impact of the recent financial crisis over this evolution.

Details regarding the independent variables selected and their expected effect on the financing decision of the firms from the countries included in the analysis can be found in table 1 above.

Data on the macroeconomic indicators were taken from World Bank (World Development Indicators and Global Financial Development Database), World Bank Financial Structure database [4], [6] and Eurostat [18].

In order to develop and grow, the firms from the emerging markets in CEE need to use external sources of financing. Thus, in the context of the recent financial crisis, we wanted to identify whether external financing of the firms was significantly affected by the changes in the macroeconomic conditions and if the firms have reduced the use of this type of financing. Based on this, we have chosen as dependent variables the followings:

- The indebtedness level (IND) expresses as a percentage, the ratio between the total debt of the enterprise and its total assets. This indicator shows the amount of leverage being used by a company. It indicates the proportion in which the total assets are financed from external resources, other than the own resources of the firms, for example: loans, suppliers, state debts. Harrison and Widjaja [21] use the leverage as a proxy for the capital structure of the firm.

- Financing through long-term liabilities (FIN_LTL) - which includes all long-term debt of the business, namely the ones for a period exceeding one year. Long-term liabilities include items like debentures, loans, deferred tax liabilities and pension obligations.

- Financing through bank loans (FIN_BL) - which includes all short-term, medium and long term financial debt to credit institutions (loans and credits). The bank loan facility fulfils an important role in analyzing the external financing of non-financial enterprises in 
developing countries in Central and Eastern Europe, because it is the main source of external financing of enterprises in these countries [23].

\subsection{Methodology}

Regression has been used frequently as the empirical methodology to investigate the determinants of capital structure [31], [3], [1], [15]. Barbosa and Moraes [3] used multiple regressions: OLS regression to do the estimation of financial leverage measure and the pooled regression to investigate the relationship between leverage and its determinants. Antoniou et al. [1, p. 10] used panel data because it would increase the degrees of freedom, minimize the possibility of collinearity among the explanatory variables, and consequently deliver more efficient estimates.

To maximize the use of all available data, we will use in this research panel data methods, which are suitable for analyzing multi-dimensional data (cross-section and time series), and a recently developed unbalanced panel regression method [1], [29].

Prior studies on capital structure have seldom used key macroeconomic factors: the exception is Drobetz and Wanzenreid [17], which used interest rate and inflation.

Considering the fact that we use relatively short time series and that are similarities between the analyzed economies, we decided to use panel regression [22], and obtain more information on the analyzed parameters.

The general form of the models used is the following:

$$
Y_{i z t}=\alpha+\beta X_{z t}+\varepsilon_{i z t}
$$

The triple subscript attached to the variables differentiates the regression equation from ordinary time-series regression or cross-section regression. The subscript $i$ and $z$ represent the cross-sectional dimensions (firms and countries) and $t$ time-series dimension. Further, $Y$ in the equation represents the dependent variable (in our case is different for every model, see table 2), $\beta$ denotes the coefficients, $X$ denotes the explanatory variables (which are explained in the table 1) in the estimation model, $a$ is the constant and finally $\varepsilon$ is assumed to be the randomly distributed error term.

Model 1: studies the impact of changes in the macroeconomic conditions from the seven CEE countries, as a result of the manifestation of the recent financial crisis, on the indebtedness level of the analyzed firms.

Model 2: studies the impact of changes in the macroeconomic conditions from the seven CEE countries, as a result of the manifestation of the recent financial crisis, on the decision of the firms to finance through long-term liabilities.

Table 2. Multiple linear regression models used

\begin{tabular}{|c|c|}
\hline Model & Equation \\
\hline Model 1 & $\mathrm{IND}_{z \mathrm{t}}=\alpha+\beta_{1} \cdot \mathrm{IRL}_{\mathrm{zt}}+\beta_{2} \cdot \mathrm{FDI}_{\mathrm{zt}}+\beta_{3} \cdot \mathrm{GDP}_{\mathrm{zt}}+\beta_{4} \cdot \mathrm{DCPV}+\beta_{5} \cdot \mathrm{CPI}+\varepsilon_{\mathrm{izt}}$ \\
\hline Model 2 & FIN_LTL ${ }_{z \mathrm{t}}=\alpha+\beta_{1} \cdot \mathrm{IRL}_{\mathrm{zt}}+\beta_{2} \cdot \mathrm{FDI}_{\mathrm{zt}}+\beta_{3} \cdot \mathrm{GDP}_{\mathrm{zt}}+\beta_{4} \cdot \mathrm{DCPV}+\beta_{5} \cdot \mathrm{CPI}+\varepsilon_{\mathrm{izt}}$ \\
\hline 3 & $\mathrm{FIN}_{-} \mathrm{BL}_{\mathrm{zt}}=\alpha+\beta_{1} \cdot \mathrm{IRL}_{\mathrm{zt}}+\beta_{2} \cdot \mathrm{FDI}_{\mathrm{zt}}+\beta_{3} \cdot \mathrm{GDP}_{\mathrm{zt}}+\beta_{4} \cdot \mathrm{DCPV}+\beta_{5} \cdot \mathrm{CPI}+\varepsilon_{\mathrm{izt}}$ \\
\hline
\end{tabular}


Model 3: studies the impact of changes in the macroeconomic conditions from the seven CEE countries, as a result of the manifestation of the recent financial crisis, on the level of bank loans contracted by the analyzed firms.

\section{Results and discussions}

The results of testing the four models are presented in this section. The statistics relating to the samples are summarized in tables 3, 4 and 5. We analyze the results obtained by each model separately.

Thus, in table 3 we present the results obtained for Model 1, which analysis the impact of the recent financial crisis (determined by the changes that appear in the macroeconomic conditions) on the indebtedness level of the firms, in the period 2004-2009.

Table 3. The impact of the financial crisis on the indebtedness level ${ }^{1}$ of the firms from the CEE countries. The statistical significance of the regression coefficients of the econometric model.

\begin{tabular}{lllllll}
\hline Variable & Constant & $I R L^{2}$ & $F D I^{3}$ & $G D P^{4}$ & $D C P V^{5}$ & $C P I^{6}$ \\
\hline Coefficients & $3.827^{* * *}$ & $-0.082^{* * *}$ & -0.015 & $0.004^{* *}$ & $0.097^{* * *}$ & $0.043^{* * *}$ \\
& $(26.415)$ & $(-2.943)$ & $(-1.749)$ & $(2.271)$ & $(3.907)$ & $(11.326)$
\end{tabular}

\begin{tabular}{l}
\hline R-squared 0.65 \\
* $^{* *}$ and ${ }^{* * *}$ denote that coefficients are significantly at the $90 \%, 95 \%$ and $99 \%$ level, respectively. The numbers \\
in parentheses are t-values. \\
${ }^{1}$ the indebtedness level of the firms (logarithmic), ${ }^{2} \log$ arithm of interest rate on loans, ${ }^{3}$ logarithm of foreign investment \\
as percent of GDP, ${ }^{4}$ real GDP growth rate, ${ }^{5}$ logarithm of financial resources provided to private sector through loans \\
(as \% of GDP), 6logarithm of the inflation rate.
\end{tabular}

Source: data processed by output from E-views 7

This model shows that the foreign investments as a share of GDP have not a statistically significant effect on the indebtedness level of the analyzed firms. Also, we observe that the interest rate on loans has a negative significant effect on the indebtedness level of the firms. The real economic growth rate, the value of domestic credit to private sector and inflation rate have a positive significant effect on the indebtedness level of the firms (the expected signs from table 1 ).

The coefficient estimates indicate that, when the interest rate on loans from the analyzed countries rises with 10\% (as an effect of the financial crisis), the indebtedness level of the firms is decreasing with $0.82 \%$. A decrease with $10 \%$ of the real GDP determines a decrease of the indebtedness level with $0.04 \%$. The same effect is observed for the domestic credit granted to private sector, which decrease determines a decrease of the indebtedness level of the firms with $1 \%$. In the case of inflation rate, a decline of the inflation rate with $10 \%$ determines a decrease of the bank loans contracted by the firms with $0.43 \%$.

At the same time, we observe that only $65 \%$ (R-squared) of the variation of the indebtedness of the firms is explained by the four observed macroeconomic variables that are considered significant, which shows that the remaining $35 \%$ of the variation is explained by other external or internal factors. The reduction in level of indebtedness of the firms from the seven countries analyzed in $2004-2009$, is due by $65 \%$ to the increase 
of the interest rate on loans and the decrease of real economic growth rate, domestic credit granted to private sector and of the inflation rate, under the impact of the financial crisis.

Because the probability associated with the test F-statistic is less than 5\% we accept with a very small error that there is a linear dependence between the level of indebtedness of the analyzed firms and the macroeconomic analyzed variables. So, since, as of 2008 , the values recorded by the four macroeconomic variables analyzed were significantly affected by the recent financial crisis, and they have a significant impact on the level of indebtedness of the firms. Thus, we consider that the recent financial crisis has had a significant effect on the level of indebtedness of the investigated firms which operate in the seven countries from CEE. As we can see from figure 1, the indebtedness level of firms had significantly decreased starting with 2008, after an ascending trend started in 2005 (see figure 1).

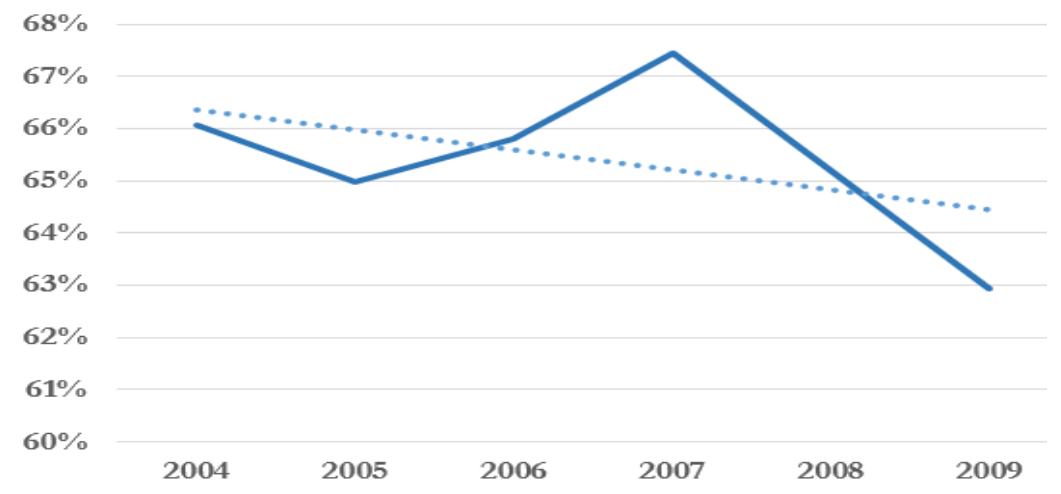

Figure 1. The evolution of the indebtedness level of the firms from CEE between 2004 and 2009

Source: author's processing after data from Amadeus database [8]

Using Model 2, we wanted to identify the impact of the financial crisis, manifested by its influence on the macroeconomic conditions, on the financing of the 245 companies in seven countries through long-term debt. Applying this model, we observe that only two variables are relevant to a statistical significance level of $1 \%$ (see table 4). Thus, the financing of enterprises in seven countries of Central and Eastern Europe by long-term debt is positively affected by the changes on the value of domestic credit granted to private sector and the inflation rate (the expected signs from table 1).

This shows that the reducing of domestic credit granted to private sector and inflation rate, in the context of the financial crisis, determines the decrease of the long-term debt used by the firms to secure their financial resources needed to conduct the business. The coefficient estimates indicate that, when the domestic credit to private sector decreases with $10 \%$, the firms reduce the use of long term debt with $21 \%$. Also, a reduction of inflation rate with $10 \%$ determines a decrease in the same direction in the use of long term debt with $2 \%$.

Because the probability associated with the test F-statistic is less than $5 \%$ we accept with a very small error that there is a linear dependence between the long term debts used by the analyzed firms and the macroeconomic analyzed variables. So, since, as of 2008 , the 
values recorded by the four macroeconomic variables analyzed were significantly affected by the recent financial crisis, and they have a significant impact on the level of long term debt used by the firms. Thus, we appreciate that the recent financial crisis has had a significant impact on the long term debt used by the 245 companies analyzed from the CEE countries, determining a decrease in using this source of financing.

Table 4. The impact of the financial crisis on the decision to finance through long-term liabilities ${ }^{1}$ of the firms from CEE countries. The statistical significance of the regression coefficients of the econometric model.

\begin{tabular}{lllllll}
\hline Variable & Constant & $\mathrm{IRL}^{2}$ & $\mathrm{FDI}^{3}$ & $\mathrm{GDP}^{4}$ & $\mathrm{DCPV}^{5}$ & $\mathrm{CPI}^{6}$ \\
\hline Coefficients & -0.887 & 0.237 & -0.199 & 0.031 & $2.146^{* * *}$ & $0.201^{* * *}$ \\
& $(-0.446)$ & $(0.828)$ & $(-1.404)$ & $(1.200)$ & $(5.259)$ & $(3.047)$
\end{tabular}

R-squared 0.83

*,** and *** denote that coefficients are significantly at the 90\%, 95\% and 99\% level, respectively. The numbers in parentheses are t-values.

${ }^{1}$ The value of firms financing through long term liabilities (logarithmic), ${ }^{2}$ logarithm of interest rate on loans, ${ }^{3}$ logarithm of foreign investment as percent of GDP, ${ }^{4}$ real GDP growth rate, ${ }^{5}$ logarithm of financial resources provided to private sector through loans (as \% of GDP), 6logarithm of the inflation rate.

Source: data processed by output from E-views 7

Model 3 is used to study the impact of the financial crisis, through changes in the macroeconomic conditions, on the bank loans contracted by the firms in order to finance their activity (see table 5). This model shows that the real economic growth rate of the seven analyzed countries and the foreign investments as a share of GDP have not a statistically significant effect on the bank loans contracted by the firms. Also, we observe that the interest rate on loans has a negative significant effect on financing through bank loans. The values of domestic credit to private sector and inflation rate have a positive significant effect on the bank loans contracted by the firms (the expected sign from table 1).

Table 5. The impact of the financial crisis on the decision to finance through bank loans ${ }^{1}$ of the firms from the CEE countries. The statistical significance of the regression coefficients of the econometric model.

\begin{tabular}{lllllll}
\hline Variable & Constant & $I R L^{2}$ & $F D I^{3}$ & $G D P^{4}$ & $D C P V^{5}$ & $C P I^{6}$ \\
\hline Coefficients & $8.083^{* * *}$ & $-2.296^{* * *}$ & -0.210 & -0.036 & $1.098^{* * *}$ & $0.958^{* * *}$ \\
& $(4.772)$ & $(-9.477)$ & $(-1.392)$ & $(-1.286)$ & $(3.087)$ & $(7.708)$
\end{tabular}

\begin{tabular}{lllllll}
\hline R-squared & 0.77 & & & & \\
\hline $\begin{array}{l}\text { Time fixed } \\
\text { effects }\end{array}$ & 2004 & 2005 & 2006 & 2007 & 2008 & 2009 \\
\hline Coefficients & 5.620 & -1.500 & 7.650 & 2.030 & -1.610 & 1.190 \\
\hline
\end{tabular}


*, ** and *** denote that coefficients are significantly at the 90\%, 95\% and 99\% level, respectively. The numbers in parentheses are t-values.

${ }^{1}$ the dependent variable is the value of bank loans contracted by the firms (logarithmic), ${ }^{2}$ logarithm of interest rate on loans, ${ }^{3}$ logarithm of foreign investment as percent of GDP, ${ }^{4}$ real GDP growth rate, ${ }^{5}$ logarithm of financial resources provided to private sector through loans (as \% of GDP), 6logarithm of the inflation rate

Source: data processed by output from E-views 7

The coefficient estimates indicate that, when the interest rate on loans from the analyzed countries rises with 10\% (in our case it have registered an increase as an effect of the financial crisis) the bank loans contracted by the firms are decreasing with $22 \%$. A decrease with $10 \%$ of the domestic credit granted to private sector determines a decrease of the bank loans contracted by the firm with almost $11 \%$. The same effect is registered in the case of inflation rate, where a decline of the inflation rate with $10 \%$ determines a decrease of the bank loans contracted by the firms with $9 \%$.

At the same time, we observe that only $77 \%$ (R-squared) of the reduction in the bank loans contracted by the firms is explained by the three observed macroeconomic variables that are considered significant, which shows that the remaining $23 \%$ of the variation is explained by other external or internal factors. The reduction in level of bank loans contracted by the firms from the seven countries analyzed in 2004-2009, is due by $77 \%$ to the increase of the interest rate on loans and the decrease of domestic credit granted to private sector and of inflation rate, under the impact of the financial crisis.

Because the probability associated with the test F-statistic is less than 5\% we accept with a very small error that there is a linear dependence between the level of bank loans contracted by the analyzed firms and the macroeconomic analyzed variables. So, since, as of 2008, the values recorded by the three macroeconomic variables analyzed were significantly affected by the recent financial crisis, and they have a significant impact on level of bank loans contracted by the firms. Hence, the recent financial crisis has had a significant impact on the level of bank loans contracted by the 245 companies analyzed from the CEE countries, determining it's decrease. These results are in line with the findings from other research papers, for example Campello et al. [10] analyzing the effect of the financial crisis on almost 400 U.S. firm found that the financial crisis limited the access of firms to credit, determining them to use more internal resources.

Also, analyzing the time effects we see that a negative effect is recorded in 2008. In 2009, the coefficient is positive, but still smaller than the one in 2007 , fact that shows that the effect of the financial crisis (by the changes in the macroeconomic conditions) is felt strongly by the decision to finance through bank loans of the analyzed firms.

\section{Conclusions}

Based on this analysis, we find that the recent financial crisis has led to unfavorable developments on non-financial enterprise sector in the analyzed countries. The offer of financing has become more restrictive in terms of price and volume. Also, the financing application has registered a significant reduction due to uncertainties aroused in the macroeconomic environment and also due to the fact that the enterprises have reduced their financing capacity. 
From the empirical analysis realized we have noticed that what could be a very good model of prediction for certain countries, does not necessarily coincide with what would fit for other countries, depends on the country profile and other characteristics of the financial environment and enterprises in that country. Moreover, the crisis affected different the enterprise from different countries, as also results from the studies conducted by the World Bank on this matter.

The general conclusion of this research conducted through multiple linear regression models is that the specific factors of the external environment of the enterprises have a significant influence on their decision of financing. When this environment becomes turbulent, the enterprises are facing serious problems in their activities. Thus, they are forced to make significant changes regarding the favorite financing sources. Thus, we consider that this research paper can contribute to the expansion of scientific knowledge in the field of enterprise financing. Analyzing a broad sample of 245 enterprises coming from seven countries has a novelty character and allows us to obtain some comprehensive results regarding the changes in the financing decision in the context of the recent financial crisis.

The deterioration of international and domestic economic environment has resulted in new barriers to the way that enterprises from the analyzed countries conduct their activity, including, primarily, the decreased domestic and external demand of goods and services, late payments from customers, significantly reducing access to credit, due to increase their costs and tighter bank lending standards.

The results obtained from the three multiple linear regression models show that in the context of the recent financial crisis, the financing decision of firms in the seven countries considered in the analysis was significantly influenced by the changes in macroeconomic factors chosen. Thus, following the shocks and macroeconomic imbalances, the analyzed firms experienced a reduction of financing by long term debt, contracting a fewer bank loans and reducing their indebtedness level. These developments were expected because they are the result of restricting liquidity in the market, the economic downturn and tightening credit conditions.

However, we cannot generalize the results of this econometric analysis because, we have to remind that the analysis performed was done on a sample of large non-financial firms. According to various studies conducted, limited access to finance has affected to a greater extent small and medium-sized enterprises which are perceived as lenders with a higher risk than the large enterprises. Therefore, in future research we propose, first, to consider the influence of more macroeconomic factors on the decision to finance the enterprise, because macroeconomic phenomena, such as the recent financial crisis or other disturbances (e.g. recession) are complex and their impact on enterprises cannot be measured only by changes in five macroeconomic factors. Secondly, we plan to extend the analysis and include in the sample small and medium enterprises, in order to highlight the differences that arise in making the decision to finance enterprises by size. In their analyze, Harrison and Widjaja [21] found that during a financial crisis a smaller firm tends to prefer debt financing, so this means that if we had realized this analysis on small and medium sized firms we may have registered an increase of financing through bank loans or long term debt. 
In the context of the recent crisis, a significant part of the business sector from the analyzed countries is strongly affected, as also in other world countries. The effects of the recent crisis on enterprises are primarily a significant decrease of the revenue, the reduced opportunities to enter on new markets, reduced access to finance and thus reduce opportunities to develop and even to survive.

We have to keep in mind that what may be a good predictive model for some countries may not coincide with what would fit for other countries, as related to the country profile, and other characteristics of the financial environment and business in that country. Moreover, the crisis has affected different the companies in different countries, primarily because the countries was different affected by the crisis. For example, in our sample Poland has registered less drastic changes in macroeconomic variables than other countries.

We did not divided our analysis in two periods because there is no academic consensus on the exact particular timing of the onset of the 2007 financial crisis in CEE countries, and choosing a certain turning point of the financial crisis occurrence would exposing the risk of overlapping period in the data set.

\section{References}

1. Antoniou, A., Guney Y., \& Paudyal, K. (2008). The Determinants of Capital Structure: Capital MarketOriented versus Bank-Oriented Institutions. Journal of Finance and Quantitative Analysis, 43(1), 59-92.

2. Ardic, O. P., Mylenko, N., \& Saltane, V. (2011). Small and Medium Enterprises: A Cross-Country Analysis with a New Data Set. Policy Research Working Paper, No. 5538. Washington, DC: World Bank. Retrieved from http://documents.worldbank.org/curated/en/967301468339577330/pdf/WPS5538.pdf

3. Barbosa, E. G., \& Moraes, C. D. C. (2004). Determinants of the firm's capital structure: The case of the very small enterprises. Economics Working Paper Archive at WUSTL, Finance, 302001.

4. Beck, Th., Demirgüç-Kunt, A., \& Levine, R. (2000). New Database on the Structure and Development of the Financial Sector. World Bank. Economic Review, 14(3), 597-605.

5. Beck, Th., Demirgüç-Kunt, A., Laeven, L., \& Maksimovic, V. (2004). The Determinants of Financing Obstacles. Journal of International Money and Finance, 25(6), 932-952.

6. Beck, Th., Demirgüç-Kunt, A., and \& Levine, R. (2010). Financial Institutions and Markets across Countries and over Time: The Updated Financial Development and Structure Database. World Bank Economic Review, 24(1), 77-92.

7. Bhamra, H. S, Kuehn, L. A, \& Strebulaev, I. A. (2010). The aggregate dynamics of capital structure and macroeconomic risk. The Review of Financial Studies, 23(12), 4187-4241.

8. Bureau van Dijk. Amadeus Database. Retrieved from http://www.imd.org/research/information/databases/amadeus.cfm

9. Campello, M., Graham, J. R., \& Harvey, C. R. (2010). The Real Effects of Financial Constraints: Evidence from a Financial Crisis. Journal of Financial Economics, 97(3), 470-487.

10. Campello, M., Giombona, E., Graham, J. R, \& Harvey, C. R. (2011). Liquidity Management and Corporate Investment during a Financial Crisis. The Review of Financial Studies, 24(6), 1944-1194.

11. Correa, P., \& Iootty, M. (2009). The Impact of the Global Economic Crisis on the Corporate Sector in Europe and Central Asia: Evidence from Firm-Level Survey. Financial Crisis Survey Enterprise Note, 9. Washington, DC: World Bank.

12. Correa, P., Iootty, M., Ramalho, R., Meza, J. R, \& Yang, J. (2010a). How firms in eastern and central Europe are performing in the post-financial crisis world. Financial Crisis Survey, Enterprise Note, 18. Washington, DC: World Bank.

13. Correa, P., Iootty, M., Ramalho, R., Meza, J. R, \& Yang, J. (2010b). How Firms in Eastern and Central Europe Fared through the Global Financial Crisis: Evidence from 2008-2010. Financial Crisis Survey, Enterprise Note, 20. Washington, DC: World Bank. 
14. De Haas, P., \& Peeters, M. (2006). The dynamic adjustment towards target capital structures of firms in transition economies. Economics of Transitions, 14(1), 133-169.

15. De Jong, A., Kabir, R., \& Nguyen, T. T (2008). Capital structure around the world: The roles of firmand country-specific determinants. Journal of Banking and Finance, 32(9), 1954-1969.

16. Demirgüç-Kunt, A., \& Maksimovic, V. (1999). Institutions, financial markets, and firm debt maturity. Journal of Financial Economics, 54(3), 295-336.

17. Drobetz, W., \& Wanzenried, G. (2006). What Determines the Speed of Adjustment to the Target Capital Structure?. Applied Financial Economics, 16(13), 941-958.

18. Eurostat. Eurostat database. Retrieved from http://ec.europa.eu/eurostat/data/database

19. Gaud, P., Jani, E., Hoesli, M., \& Bender, A. (2005). The Capital Structure of Swiss Companies: an Empirical Analysis Using Dynamic Panel Data. European Financial Management, 11(1), 51-69.

20. Graham, J., \& Harvey, C. (2001). The theory and practice of corporate finance: evidence from the field. Journal of Financial Economics, 60(2), 187-243.

21. Harrison, B., \& Widjaja, T. W. (2013). Did the financial crisis impact on the capital structure of firms?. Discussion Papers in Economics, 5. Nottingham Trent University. Retrieved from https://www4.ntu.ac.uk/nbs/document uploads/151944.pdf

22. Hsiao, C. (2003). Analysis of panel data. Second edition. Cambridge: Cambridge University Press.

23. International Finance Corporation. (2014). Access to finance. Annual Review. World Bank Group.

24. Jinjarak, Y. (2015). Supply chains, global financial shocks and firm behaviour towards liquidity needs. The World Economy, 38(1), 425-444.

25. Kindleberger, C. P, \& Aliber, R. Z. (2005). Manias, Panics, and Crashes. A History of Financial Crises. Fift edition. New Jersey: John Wiley \& Sons, Inc.

26. Klapper, L., Sarria-Allende, V., \& Sulla, V. (2002). Small- and Medium-Size Enterprise Financing in Eastern Europe. World Bank Policy Research Working Paper, 2933. Washington, DC: World Bank.

27. Mazur, K. (2007). The Determinants of Capital Structure Choice: Evidence from Polish Companies. International Advances in Economic Research, 13(4), 495-514.

28. Nivorozhkin, E. (2005). Financing Choices of Firms in EU Accession Countries. Emerging Markets Review, 6(2), 138-169.

29. Ozkan, A. (2001). Determinants of Capital Structure and Adjustment to Long Run Target: Evidence from UK Company Panel Data. Journal of Business Finance \& Accounting, 28(1-2), 175-198.

30. Panno, A. (2003). An empirical investigation on the determinants of capital structure: the UK and Italian experience. Applied Financial Economics, 13(2), 97-112.

31. Rajan, R. G, \& Zingales, L. (1995). What Do We Know about Capital Structure? Some Evidence from International Data. Journal of Finance, 50(5), 1421-1460.

32. Serghiescu, L., \& Văidean, V. L. (2014). Determinant Factors of the Capital Structure of a Firm - an Empirical Analysis. Procedia Economics and Finance, 15, 1447-1457.

33. World Bank. World Development Indicators. Retrieved from http://data.worldbank.org/datacatalog/world-development-indicators

34. World Bank. Global Financial Development Database. Retrieved from http://www.worldbank.org/en/publication/gfdr/data/global-financial-development-database

35. Zou, H., \& Xiao, J. Z. (2006). The financing behaviour of listed Chinese firms. The British Accounting Review, 38(3), 239-258. 